\title{
Harvest times and seed germination of three safflower genotypes
}

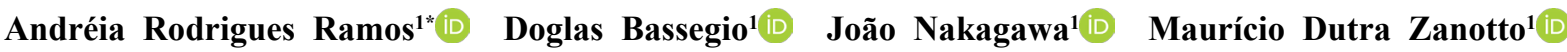

${ }^{1}$ Departamento de Produção e Melhoramento Vegetal, Faculdade de Ciências Agronômicas, Universidade Estadual Paulista "Júlio de Mesquita Filho" (UNESP), 18603-970, Botucatu, SP, Brasil. E-mail: andreia-agro@hotmail.com. "Corresponding author.

\begin{abstract}
The safflower (Carthamus tinctoriusL.) has an uneven flowering and fruiting, which can cause problems in seed production and harvesting in regions with hot and humid climates. However, little is known about the optimal safflower harvest time. Therefore, this study evaluated the optimumtiming for seed harvest of three safflower genotypes (2106, S-325, and 7329). The experiment was a randomized complete block design with six replications. The harvest started 16 days after flowering (DAF) and ended at 52 DAF. Ten harvests were made in total. Seed water content, seeds fresh and dry matter, seed germination, and first germination counts were evaluated.Genotypes 2106 and 7329 had germination rates of $79 \%$ and $91 \%$, respectively, at 34 and 38 DAF, while genotype S-325 had 90\% germination at 37 DAF. Harvesting at $52 \mathrm{DAF}$ combined with a rainy season impaired the germination of safflower seeds. The harvest time most suitable for safflower occurred between 34 and $42 D A F$, when the seeds have the seed water content between $26 \%$ and $33 \%$.
\end{abstract}

Key words: Carthamus tinctorius L., germination, physiological maturation.

Épocas de colheita e germinação de sementes de três genótipos cártamo

RESUMO: O cártamo (Carthamus tinctoriusL.) apresenta flores e frutos irregulares, o que pode causar problemas na produção e colheita de sementes em regiões com clima quente e úmido. No entanto, pouco se sabe sobre o tempo ideal de colheita de cártamo. Portanto, o objetivo desteestudo foi avaliar o momento ideal para a colheita de sementes de três genótipos de cártamo(2106, S-325 e 7329). $O$ experimento foi delineado em blocos casualizados, com seis repetições. A colheita começou 16 dias após o florescimento (DAF) e terminou aos 52 DAF. Dez colheitas foram feitas no total. Foram avaliados o teor de água das sementes, matéria fresca e seca das sementes, germinação das sementes e primeira contagem de germinação. Os genótipos 2106 e 7329 tiveram taxas de germinação de $79 \%$ e $91 \%$, respectivamente, aos 34 e 38 dias após a floração (DAF), enquanto o genótipo S-325 teve $90 \%$ de germinação aos 37 DAF. A colheita aos 52 DAF combinada com uma estação chuvosa prejudicou a germinação das sementes de cártamo. A época de colheita mais adequada para o cártamo ocorreu entre 34 e 42 DAF, quando as sementes apresentam teor de água entre $26 \%$ e $33 \%$.

Palavras-chave: Carthamus tinctorius L., germinação, maturação fisiológica.

\section{INTRODUCTION}

The safflower (Carthamus tinctorius L.) is an annual oilseed crop belonging to the Asteraceae family adapted for cultivation under semi-arid conditions (FLEMMER et al., 2015). The seeds are called achenes, have considerable protein $(15 \%$ $16 \%)$ and lipid $(23 \%-41 \%)$ contents, standing out the linoleic content $(72 \%-84 \%)$ and oleic $(7 \%-18 \%)$ acids in its oil (AL SURMI et al., 2016; KHALID et al., 2017). Although, it has greater importance for human nutrition, safflower oil also has satisfactory characteristics for biodiesel production. High linoleic acid content of safflower oil provides advantages over other oils with respect to the plugging point of the cold filter, cloud point and pour point (MIHAELA et al., 2013).

Safflower production in Brazil is unremarkable, but current research has shown potential for cultivation (SANTOS et al., 2018). Safflower could become an important crop in the Brazilian tropical conditions, which have a long dry period with high temperatures during the winter. However, cultivars with high yield are necessary for safflower to be able to compete with other oilseeds, especially soybeans (Glycine max L.). Seeds are one of the main inputs of agriculture, seed quality is one of the main factors to increase production (AGUILERA et al., 2000). To obtain seeds with high physiological quality is important to determine the optimal seed 
harvest time, which frequently corresponds to the season when physiological maturity is reached, coinciding with the moment of maximum seed dry matter, high vigor and high germination (CARVALHO \& NAKAGAWA, 2012). Harvest delay with the occurrence of adverse environmental conditions, insect attacks, and all microorganisms increase the likelihood of seed deterioration. This damage can be even more aggressive in tropical regions, mainly due to the hot and humid climate, which can accelerate the process of seed deterioration (FORTI et al., 2015). For this reason, studies are needed to determine the optimal time to harvest seeds for different species and varieties (JACOB JUNIOR et al., 2014).

Theoptimal seed harvest time is at physiological maturity. From this point on, there is no significant increase in seed dry matter (TERASAWA et al., 2009). Morphological and physiological changes that occur during the maturation process have been used as parameters to identify the optimal harvest time; these include changes in fruit color, fruit size, seed weight, and water content (ARAÚJO et al., 2006). Studies into seed maturation and harvest are important in minimizing the effects of deterioration caused by prolonged time spent in the field. In addition, seed production can be increased, since harvesting at the optimal time decreases the number of immature seeds (ALKIMIM et al., 2016). In addition to varying for each crop, the point of maturity may vary depending on the cultivar (CARVALHO \&NAKAGAWA, 2012). Although, safflower is becoming an important oilseed species, few studies were con- ducted to investigate optimal harvest time. This study evaluated the optimal seed harvest time of three safflower genotypes.

\section{MATERIALS AND METHODS}

The experiment was conducted in Botucatu in the state of São Paulo in Brazil (48 25' $\mathrm{W}, 22^{\circ} 51^{\prime} \mathrm{S}, 777 \mathrm{~m}$ above sea level). The soil was Rhodic Acrudox (SOIL SURVEY STAFF, 2014). Chemical analysis indicated $\mathrm{pH} 5.1$ in $\mathrm{CaCl}_{2}(0.01$ mol L $\left.{ }^{-1}\right) ; 27 \mathrm{~g} \mathrm{dm}^{-3}$ organic matter; $34 \mathrm{mg} \mathrm{dm}^{-3} \mathrm{P}$ (Resin-P); $7 \mathrm{mmol}_{\mathrm{c}} \mathrm{dm}^{-3} \mathrm{~K}^{+} ; 48 \mathrm{mmol}_{\mathrm{c}} \mathrm{dm}^{-3} \mathrm{Ca}^{2+}$; $17 \mathrm{mmol}_{\mathrm{c}} \mathrm{dm}^{-3} \mathrm{Mg}^{2+} ; 105 \mathrm{mmol}_{\mathrm{c}} \mathrm{dm}^{-3}$ of cation exchange capacity (CEC); and $68 \%$ base saturation. The soil consisted of $630 \mathrm{~g} \mathrm{~kg}^{-1}$ sand, $90 \mathrm{mg} \mathrm{kg}^{-1}$ silt, and $280 \mathrm{~g} \mathrm{~kg}^{-1}$ clay.

The climate was Cwa, according to the Köppen climate classification system: tropical with dry winters and hot rainy summers. The 1956-2013 mean annual maximum and minimum temperatures were 26.1 and $15.3{ }^{\circ} \mathrm{C}$; respectively, with a mean annual precipitation of $1358 \mathrm{~mm}$. Precipitation and temperature were measured during this study (Figure1).

Three safflower genotypes (2106, S-325, and 7329) obtained from the Matogrossense Institute of Cotton (IMAmt) were evaluated. Sowing was conductedon April 25, 2016. The experiment was a randomized complete block design (RCBD) with six replications. The line spacing was $0.45 \mathrm{~m}$. The plant density was 222 thousand plants $\mathrm{ha}^{-1}$. The experimental plots had dimensions of $11.25 \mathrm{~m}^{2}$.

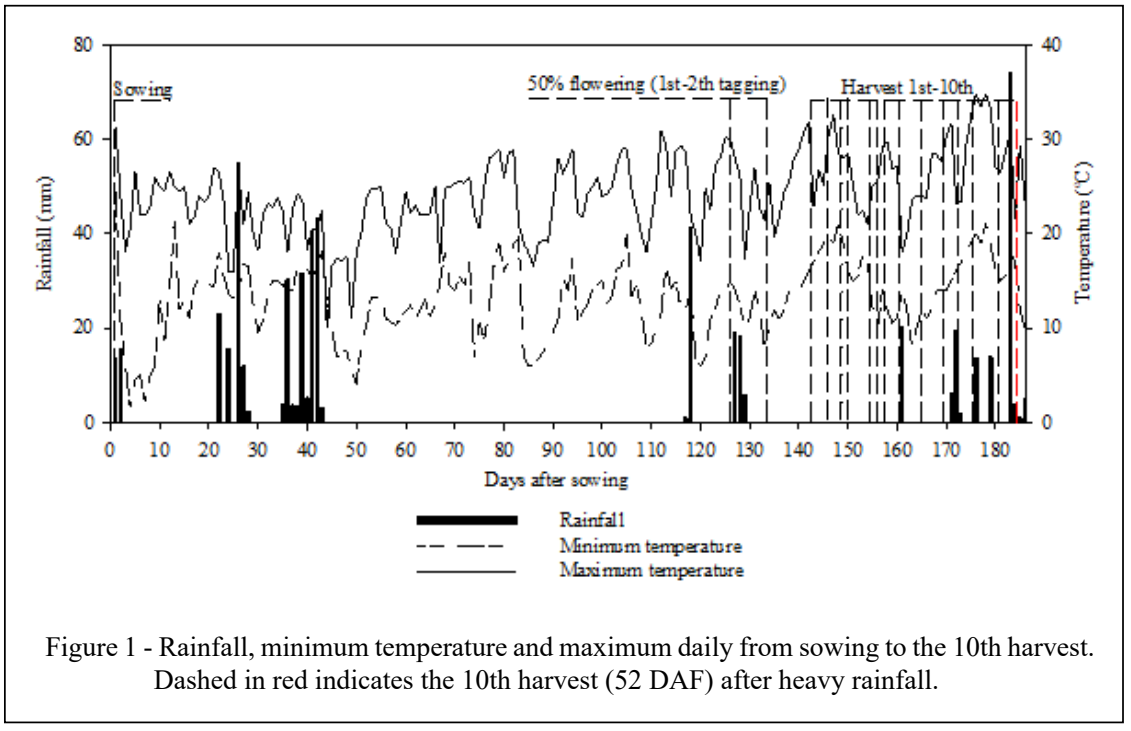

Ciência Rural, v.51, n.5, 2021. 
Fertilizer was applied at $30 \mathrm{~kg} \mathrm{ha}^{-1} \mathrm{~N}, 84 \mathrm{~kg} \mathrm{ha}^{-1} \mathrm{P}_{2} \mathrm{O}_{5}$, and $48 \mathrm{~kg} \mathrm{ha}^{-1} \mathrm{~K}_{2} \mathrm{O}$. Weeds were manually controlled.

The first tagging was performed when $50 \%$ of the plants in the plot were in full bloom. The central stem flower head and the head close to the primary branch were considered. The plans for the three central lines were tagged. Head tagging was considered the standard (control). Two labels were made, the first on August 29, 2016 on plots with more than $50 \%$ flowering plants and the second on September 4, 2016.

Heads were harvested at four-day intervals after the first harvest. The harvest started 16 days after flowering (DAF) and ended at 52 DAF. Ten harvests were made in total. The heads were manually harvested at 6:20 am. The involucral bracts of each heads were differentiated, as proposed by FLEMMER et al. (2015).

Seed water content was determined according to the recommendations of the Rules for Seed Analysis (BRASIL, 2009), in an oven at $105 \pm$ $3{ }^{\circ} \mathrm{C}$ for $24 \mathrm{~h}$, using three replicates of 20 seeds, with the results expressed as a percentage.

The seeds were weighed on an analytical balance with an accuracy of $0.0001 \mathrm{~g}$. The seed dry matter was obtained in an oven at $105 \pm 3{ }^{\circ} \mathrm{C}$ for $24 \mathrm{~h}$, with three repetitions of 20 seeds each.

A germination test was conducted with four replicates of 50 seeds, sown between three sheets of Germitest paper, moistened with deionized water, with matter equivalent to 2.2 times the weight of dry paper. Paper rolls were made, which were held upright in germination at a temperature of $25^{\circ} \mathrm{C}$. Evaluations were conducted at 4 and 14 days after sowing, according to the criteria established by the Seed Analysis Rules (BRASIL, 2009). Seeds were considered germinated when the radicle protruded to a minimum length of $2 \mathrm{~mm}$. Results were expressed as a percentage.

The first germination count was undertaken along with the germination test, determining the percentage of normal seedlings on the fourth day after sowing (BRASIL, 2009). Results were expressed as the percentage of normal seedlings.

All data were tested for normality and then subjected to analysis of variance by the F test using the Sisvar software, version 5.6. For harvest times, a regression analysis was performed, based on the significance of the model coefficients and the value of the determination coefficient $\left(\mathrm{R}^{2}\right)$, using Sigma Plot 11.0. Harvest at 52 DAF was not considered in the regression analysis.

\section{RESULTS}

Seed water content decreased linearly $(\mathrm{P}<0.05)$ in the three safflower genotypes, from the first harvest at 16 days after flowering (DAF) to harvest at $48 \mathrm{DAF}$. At $52 \mathrm{DAF}$, a point outside the curve was observed, where the water content increased from $10 \%$ to more than $30 \%$ in the three genotypes. On average, the seed lost approximately $1.61 \%, 1.91 \%$, and $1.92 \%$ of its water content daily for genotypes $2106, \mathrm{~S}-325$, and 7329 , respectively. The seed water content at $16 \mathrm{DAF}$, was $69 \%, 67 \%$, and $66 \%$ for genotypes $2106, \mathrm{~S}-325$, and 7329 , respectively, but fell sharply to reach approximately $10 \%, 8 \%$, and $3 \%$ at 48 DAF respectively (Figures 2A, C, and E).

Maximum seed fresh matter occurred at 24, 21 , and 16 DAF for genotypes 2106, S-325, and 7329, respectively. Maximum seed dry matter occurred at 36, 40, and 40 DAF for genotypes 2106, S-325, and 7329, respectively. Maximum seed dry matter accumulation was 2.16, 2.12, and $2.04 \mathrm{~g}$ for genotypes 2106, S-325, and 7329 , respectively (Figures $2 \mathrm{~B}, \mathrm{C}$, and F). Harvest times strongly influenced $(\mathrm{P}<0.05)$ seed germination. Genotype 2106 had maximum seed germination at 34 DAF (79\%), while genotype S-325 had 90\% seed germination at 37 DAF. Genotype 7329 had 91\% seed germination at 38 DAF. From that time onward; however, seed germination decreased, reaching 54\%, $67 \%$ and $78 \%$ at 48 DAF for genotypes 2106, S-325, and 7329, respectively (Figures 3A, C, and E).

The highest first germination count for genotypes 2106, S-325, and 7329 were obtained at 42 DAF, with values of $74 \%, 86 \%$, and $84 \%$, respectively. At 16 and $20 \mathrm{DAF}$, there were no normal seedlings. Only $25 \%$ and $16 \%$ of the seeds germinated in the first count at 30 DAF for genotypes 2106 and S-325, respectively, but increased to $74 \%$ and $84 \%$ at 42 DAF (Figures 3B, D, and F).

\section{DISCUSSION}

During harvested at different times, decline steady in seed water content was observed. This corresponds to physiological maturity of seeds (CARVALHO \& NAKAGAWA, 2012; ALKIMIM et al., 2016). However, notably the water content of the seed alone is not a good indicator of physiological maturation, as it can be influenced by genetic and environmental conditions. After its formation, the seed has a high water content (CARVALHO \&NAKAGAWA, 2012) that is necessary for the 


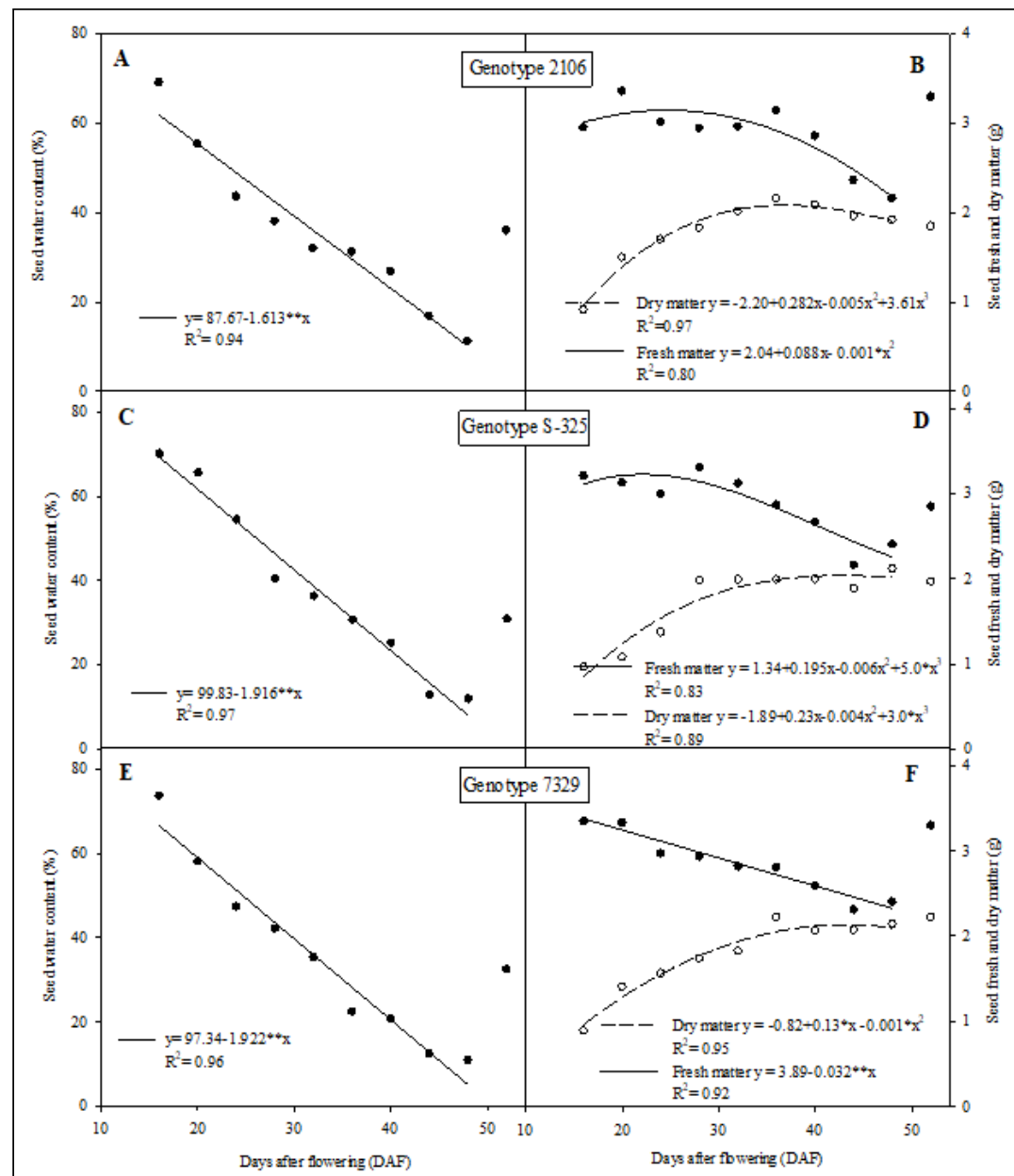

Figure 2 - Seed water contentof genotypes 2106 (A), S-325 (C), and 7329 (E); seed fresh and dry matter of genotypes 2106 (B), S-325 (D), and 7329 (F). ${ }^{* *},{ }^{*}$ Significant at $P<$ 0.01 , and $P<0.05$ probability, respectively.

translocation of the plant's metabolites to the seeds and for cell expansion (BEWLEY et al., 2013). This can be justified by its need to synthesize and metabolize reserve materials that occur in an aqueous medium (MARROCOS et al., 2011). At 52 DAF, water content increased from $10 \%$ to more than $30 \%$ in the three genotypes due to intense periods of rain (Figure 1). Rainy periods can damage Safflower seeds, resulting in reduced seed germination, as observed at 52 DAF. In fact, at 52 DAF (180 days after emergency) the harvest was delayed. In Brazilian Southeast the cultivar cycle was around 160 days (SANTOS et al., 2018). Excessive delay in harvesting safflower brought great loss in seed quality. This problem in the harvest has been reported in cultivated sunflowers due to the hot and humid climate in areas of cultivation.

The decrease in seed fresh matter occurred more quickly compared to seed dry matter accumulation. This decrease is probably due to losses caused by the intense respiration of the seeds (ARAÚJO et al., 2006). According to CARVALHO \& NAKAGAWA (2000), seed dry matter is maintained for a few days, and there may be a small decrease over time due to losses from the respiration. The maximum seed dry matter accumulation was close to the germination values, which indicates that the genotype harvest time was around 40 DAF.

Seed germination was low in the genotype S-325 (79\%), which may be due to the high water content in the seed maturation stage (CARVALHO 


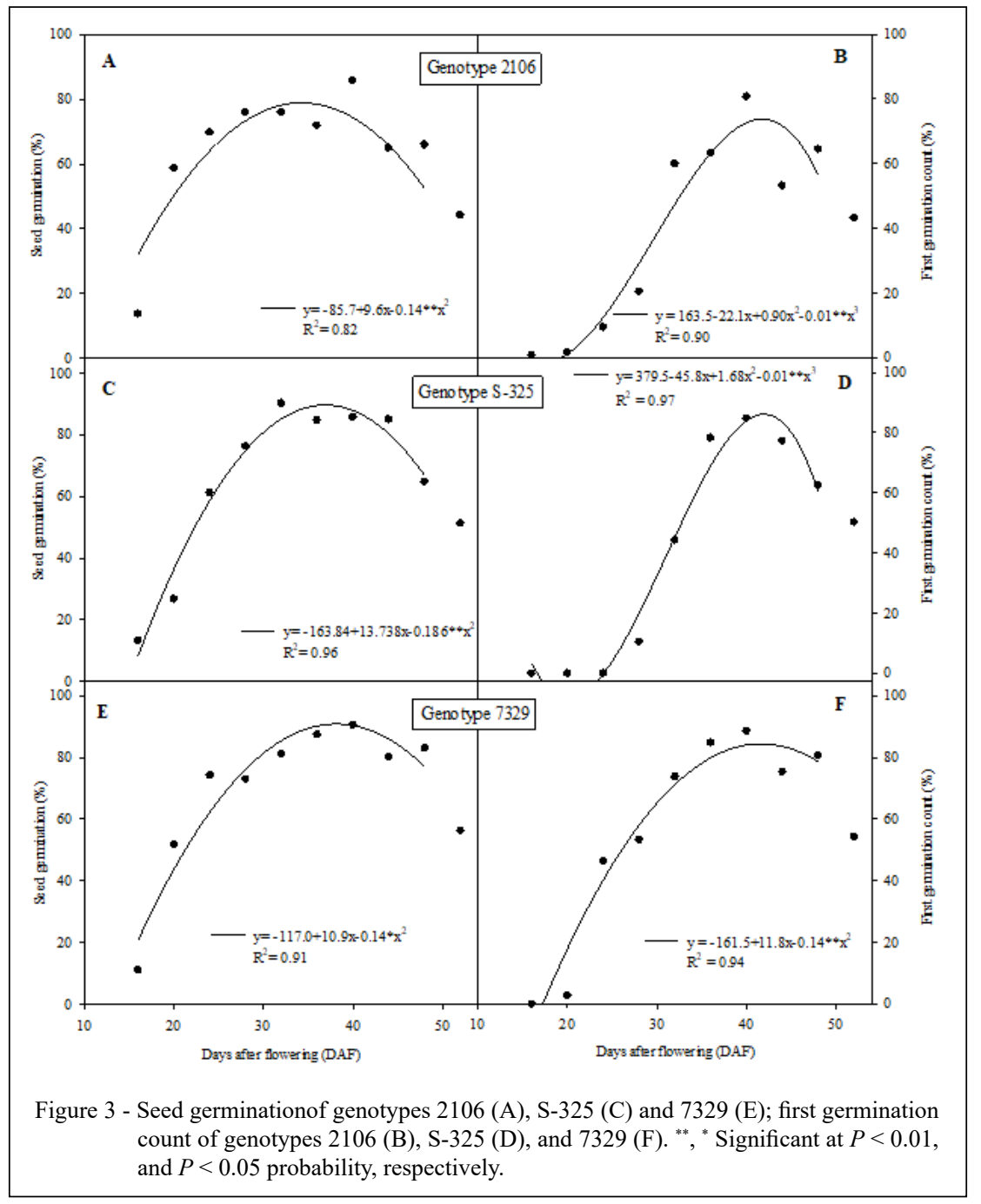

\& NAKAGAWA, 2012). In the development phase (immature embryo), seeds had a high water content and from that stage of maturation, there was a constant reduction in germination. After the seeds reached physiological maturity, they started to deteriorate, which led to the loss of germination capacity (ROCHA et al., 2014). Knowledge of the time of physiological maturity in safflower would allow program harvest time to avoid seed sprouting in the heads (SHAKERI-AMOUGHIN et al., 2012). Because of their high water and oil content, oilseed exhibit a great loss in quality when they are kept on plants after maturity (SHAKERIAMOUGHIN et al., 2012). Seeds harvested at 52 DAF were impaired, which coincided with a rainy period. Seed damage became increasingly dramatic and irreversible.
Maximum seed germination for genotypes 2106, 7329, and S-325 occurred when the seeds have the seed water content of $33 \%, 27 \%$, and $26 \%$, respectively (Figures $2 \mathrm{~A}, \mathrm{~B}$ and $\mathrm{C}$ ). In safflower, FRANCHINI et al. (2014) observed that the mean seed water content at physiological maturity was $39 \%$. The physiological maturity depends on genotype and edaphoclimatic cultivation conditions (FRANCHINI et al., 2014). Seed germination is an important aspect to increase safflower grain yield. In this sense, SOLEYMANI (2019) observed a significant correlation between seed germination and grain yield. The maximum potential for germination (36 DAF) occurred few days before the maximum accumulation of dry matter (39 DAF) for the three genotypes. The maximum dry matter accumulation, maximum germination capacity and 
vigor characterize the period when the seed reaches its physiological maturity. Frequently maximum seed dry matter accumulation coincides with high germination (CARVALHO \& NAKAGAWA, 2012).

Higher seed germination and first germination counts were obtained between 34 and 42 DAF. The relationship between seed dry matter, seed water content and seed quality has been studied only in one safflower cultivar grown in Iran (SHAKERI-AMOUGHIN et al., 2012). SHAKERI-AMOUGHIN et al. (2012) observed that seed safflower reached physiological maturity 42 $\mathrm{DAF}$ and maximum emergence rate were obtained between 45 and 55 DAF.

\section{CONCLUSION}

The harvest time most suitable for safflower occurred between 34 and 42DAF, when the seeds have the seed water content between $26 \%$ and $33 \%$. These results can be used to improve the production of safflower seeds and indicate the appropriate time for safflower harvest.

\section{ACKNOWLEDGEMENTS}

The research was financed in part by the Coordenação de Aperfeiçoamento de Pessoal de Nível Superior - Brasil (CAPES) - Finance code 001.

\section{DECLARATION OF CONFLICTS OF INTERESTS}

The authors declare no conflict of interest. The founding sponsors had no role in the design of the study; in the collection, analysis, or interpretation of data; in the writing of the manuscript, and in the decision to publish the results.

\section{AUTHORS' CONTRIBUTIONS}

ARR, JN and MDZ conceived and designed experiments. ARR performed the experiments and carried out the lab analyses. MDZ supervised and coordinated the experiments. ARR performed statistical analyses of experimental data. ARR and DB prepared the draft of the manuscript. All authors critically revised the manuscript and approved of the final version.

\section{REFERENCES}

AL SURMI, N.Y. et al. Chemical and nutritional aspects of some safflower seed varieties. Journal of Food Processing and Technology, v.7, n.5, p.1-5, 2016. Available from: <https://doi. org/10.4172/2157-7110.1000585>. Accessed: Aug. 31, 2020. doi: $10.4172 / 21577110.1000585$.

ALKIMIM, E. R. et al.Different harvest times and physiological quality of coriander seeds. Revista Brasileira de Engenharia Agrícola e Ambiental, v.20, n.2, p.133-137, 2016. Available from:
$<$ https://doi.org/10.1590/1807-1929/agriambi.v20n2p133-137>. Accessed: Jun. 10, 2020. doi: 10.1590/1807-1929/agriambi. v20n2p133-137.

ARAÚJO, E. F. et al. Qualidade fisiológica de sementes de milho-doce colhidas em diferentes épocas. Bragantia, v.65, n.4, p.687-692, 2006. Available from: $<$ https://doi.org/10.1590/S000687052006000400020>. Accessed: Jun. 10, 2020. doi: 10.1590/ S0006-87052006000400020.

BEWLEY, J. D. et al. Seeds: physiology of development, germination and dormancy. Springer Science \& Business Media, 2012, p.392. Available from: <https://doi.org/10.1007/978-14614-4693-4>. Accessed: Jun. 06, 2020. doi: 10.1007/978-14614-4693-4.

BRASIL. Ministério da Agricultura, Pecuária e Abastecimento. Regras para análise de sementes. Brasília, 2009. 395p.

CARVALHO, N.M.; NAKAGAWA, J. Sementes: ciência, tecnologia e produção. 4.ed. Jaboticabal: FUNEP, 2000. 588p.

CARVALHO, N. M., NAKAGAWA, J.Sementes: ciência, tecnologia e produção. 5. ed. Jaboticabal: FUNEP, 2012. 590p.

FLEMMER, A. C. et al. Description of safflower (Carthamus tinctorius) phenological growth stages according to the extended BBCH scale. Annals of Applied Biology, v.166, n.2, p.331339, 2015. Available from: <https://doi.org/10.1111/aab.12186>. Accessed: Jun. 06, 2020.doi:10.1111/aab.12186.

FRANCHINI, M.C. et al. Fruit development of two high oleic safflower (Carthamus tinctorius L.) cultivars. Revista Internacional de Botánica Experimental, v.83, n.2, p.379388, 2014. Available from: <https://doi.org/10.32604/ phyton.2014.83.379>. Accessed: Aug. 31, 2020. doi: 10.32604/ phyton.2014.83.379.

FORTI, V. A. et al. Meloidogyne javanica infection of soybean plants: plant response, seed quality and green seeds occurrence. Seed Science and Technology, v.43, n.3, p.409-420, 2015.Available from: $<$ https://doi.org/10.15258/sst.2015.43.3.08>. Accessed: Jun. 06, 2020.doi:10.15258/sst.2015.43.3.08.

JACOB JUNIOR, E. A. et al.Ideal seeds harvest moment of different maize hybrids. Ciência Rural, v.44, n.2, p.253260, 2014.Available from: <https://doi.org/10.1590/S010384782014000200010>. Accessed: Jun. 06, 2020. doi: 10.1590/ S0103-84782014000200010.

KHALID, N. et al. comprehensive characterization of safflower oil for its potential applications as a bioactive food ingredient - a review. Trends in Food Science and Technology, v.66, p.176-186, 2017. Available from: <https://doi.org/10.1016/j. tifs.2017.06.009>. Accessed: Jun. 06, 2020.doi: 10.1016/j. tifs.2017.06.009.

MARROCOS, S.D.T.P. et al. Maturação de sementes de abobrinha menina brasileira. Revista Brasileira de Sementes, v. 33, n.2, p. 272-278, 2011. Available from: <http://dx.doi.org/10.1590/ S0101-31222011000200009>. Accessed: Jun. 23, 2020. doi: 10.1590/S0101-31222011000200009.

MIHAELA, P. et al. Perspectives of safflower oil as biodiesel source for South Eastern Europe (comparative study: Safflower, soybean and rapeseed). Fuel, v.111, p.114-119, 2013. Available 
from: <https://doi.org/10.1016/j.fuel.2013.04.012>. Accessed: Jun. 06, 2020. doi: 10.1016/j.fuel.2013.04.012.

ROCHA, C. R. M. D. et al.Internal morphology and germination of sunflower seeds. Journal of Seed Science, v.36, n.1, p.4853, 2014. Available from: <https://doi.org/10.1590/S231715372014000100006>. Accessed: Jun. 06, 2020. doi: 10.1590/ S2317-15372014000100006.

SANTOS, R. F. et al. Irrigated safflower in phenological stages of Brazilian Southeast dry season. Irriga, v.23, n.3, p.493-504, 2018. Available from: <http://dx.doi.org/10.15809/ irriga.2018v23n3p493-504>. Accessed: Aug. 31, 2020. doi: 10.15809/irriga.2018v23n3p493-504.

SHAKERI-AMOUGHIN, R., A. et al. Evaluation of some qualitative and quantitative traits, strength and quality of safflower seeds obtained from water and dry growing conditions and different plant densities in greenhouse conditions. International Research Journal of Applied and Basic Sciences, v.3, n.3, p.545555, 2012. Available from: <http://www. irjabs.com>. Accessed: Jun. 06, 2020.

SOIL SURVEY STAFF.Keys to soil taxonomy. 11. ed. Washingthon, USDA-Natural Resources Conservation Service. 2014, p.338.

SOLEYMANI, A. Safflower (Carthamus tinctorius L.) seed vigor tests for the prediction of field emergence. Industrial Crops and Products, v.131, p.378-386, 2019. Available from: <https://doi. org/10.1016/j.indcrop.2017.03.022>. Accessed: Aug. 01, 2020. doi:10.1016/j.indcrop.2017.03.022.

TERASAWA, J. M. et al. Antecipação da colheita na qualidade fisiológica de sementes de soja. Bragantia, v.68, n.3, p.765-773, 2009. Available from: < https://doi.org/10.1590/S0006-87052009000300025>. Accessed: Jun. 06, 2020. doi: 10.1590/S0006-87052009000300025. 